\title{
Influence of Increased Pulmonary Vascular Pressures on the Closure of the Ductus Arteriosus in Newborn Lambs
}

\author{
RONALD I. CLYMAN, FRANÇOISE MAURAY, MICHAEL A. HEYMANN, AND \\ CHRISTINE ROMAN \\ Cardiovascular Research Institute and the Department of Pediatrics, University of California, San Francisco, and \\ the Department of Pediatrics, Mt. Zion Hospital and Medical Center, San Francisco, California 94143
}

\begin{abstract}
Neonatal conditions associated with increased pulmonary artery pressure have an increased incidence of patent ductus arteriosus. We operated on 15 near term fetal lambs and placed mechanical occluders into or around both branch pulmonary arteries so that main pulmonary artery blood pressure could be controlled. The lambs were delivered and ventilated for $4 \mathrm{~h}$. In seven lambs, the branch vessels were obstructed so that pulmonary artery pressure increased to equal aortic pressure; in eight lambs (control), the branch vessels were not obstructed. There were no significant differences between the two groups in circulating prostaglandin $E_{2}$ or 6 keto $F_{1 \alpha}$ concentrations, $\mathrm{PaO}_{2}, \mathrm{pH}$, or $\mathrm{PaCO}_{2}$. Despite these similarities, ductus resistance in the lambs with elevated pulmonary pressure was significantly less than that in the control lambs. After the $4 \mathrm{~h}$ measurements, we studied the ductus in vitro. We have previously found that ductus arteriosus constriction produces ischemia of its muscle wall that limits its ability to dilate or constrict any further. Ductus from lambs with elevated pulmonary pressure had a significantly increased ability to respond to oxygen, prostaglandin $E_{2}$, and indomethacin compared with ductus from control lambs; these findings are consistent with less ductus constriction in vivo. Thus, the high incidence of patent ductus arteriosus in neonates with elevated pulmonary vascular resistance may be due in part to the increased pulmonary vascular pressure, which opposes ductus constriction and preserves ductus responsiveness. Conversely, the normal drop in pulmonary pressure that occurs in full term infants may facilitate the closure of the ductus after delivery. (Pediatr Res 25: 136-142, 1989)
\end{abstract}

\section{Abbreviations}

PDA, patent ductus arteriosus

$\mathrm{PG}$, prostaglandin

$\mathrm{F}_{\mathrm{i}} \mathrm{O}_{2}$, fraction of inspired oxygen

Quv, left ventricular output

$\dot{\mathrm{Q}}_{\text {ductus }} \mathrm{L} \rightarrow \mathrm{R}$, left to right blood flow through the ductus arteriosus

$\dot{\mathrm{Q}}_{\text {ductus }} \mathrm{R} \rightarrow \mathrm{L}$, right to left blood flow through the ductus arteriosus

$\dot{\mathrm{Q}}_{\text {ductus }}$-total, total combined blood flow through the ductus arteriosus

QFo, right to left blood flow through the foramen ovale

Received January 21, 1988; accepted September 20, 1988.

Correspondence Ronald I. Clyman, M.D., 1403 HSE, Box 0544, University of California, San Francisco, San Francisco, CA 94143.

Supported by grants from the United States Public Health Service, SCOR HL27356, and Program Project Grant HL24056.
$\mathbf{R}_{\text {ductus, }}$ ductus arteriosus resistance

$\mathbf{P}_{\mathrm{pa}}$, pulmonary arterial blood pressure

$\dot{Q}_{\text {pulm, }}$ pulmonary blood flow

PIP, peak inspired ventilator pressure

IMV, ventilator rate

HR, heart rate

$\mathbf{P}_{\mathrm{AO}}$, aortic blood pressure

$\mathbf{P}_{\text {svc, }}$, superior vena caval blood pressure

$\mathbf{P}_{\text {LVED }}$, left ventricular end diastolic pressure

6 keto $\mathrm{PGF}_{1 \alpha}$, prostaglandin 6 keto $\mathrm{F}_{1 \alpha}$

Alterations in the balance between the constricting effect of oxygen and the vasodilating effect of prostaglandins play a significant role in the incidence of PDA (1). However, little attention has been paid to the effect that changes in ductus luminal blood pressure might have on the rate of ductal closure. One might expect that the greater the intravascular pressure, which opposes ductus constriction, the slower the rate of ductus closure, i.e. the greater the pressure load against which the ductus smooth muscle constricts, the greater the amount of work it must perform to achieve the same degree of constriction.

Several observations lead one to expect that changes in luminal pressure will affect ductus resistance by altering the caliber of the vessel: l) In utero, the circulating $\mathrm{PaO}_{2}$ is low and prostaglandin $\mathrm{E}_{2}$ concentration is high so that the ductus is dilated; pulmonary vascular resistance and pressure is greater than systemic vascular resistance and pressure $(2,3)$. When ductus constriction is induced in utero, there is a tendency for the ductus to constrict first at the end with the lower resistance vascular bed: the aortic end (3). 2) After delivery, pulmonary vascular resistance and pressure decreases compared with systemic vascular resistance and pressure. Ductal constriction after delivery also tends to occur first at the end with the lower resistance vascular bed; however, this time it is the pulmonic end (4). 3) Full term infants rarely have evidence of a PDA $48 \mathrm{~h}$ after delivery; however, those infants who have idiopathic pulmonary hypertension after delivery frequently have delayed closure of their ductus arteriosus (57). We hypothesized that the normal decrease in pulmonary vascular resistance and pressure that occurs in healthy, full term infants after delivery would decrease the force that opposes ductus constriction, and facilitate ductus closure. Conversely, clinical situations, associated with increased pulmonary vascular resistance and pressure, would offer a greater intravascular distending force to oppose ductus constriction and would be associated with delayed closure of the ductus. We therefore studied the effect of increased pulmonary vascular pressure on the ability of the ductus arteriosus to constrict after delivery. 


\section{MATERIALS AND METHODS}

Neonatal lambs-in vivo. Fifteen mixed breed, Western, timedated, pregnant ewes at 138-142 days of gestation $(140 \pm 1, \pm$ SD days, term 145 days) were operated on under epidural anesthesia. Ketamine was administered for sedation to the ewe every $15-30 \mathrm{~min}$ as needed (usually a total of $250-300 \mathrm{mg}$ ). Local anesthesia with $0.25 \%$ lidocaine hydrochloride was used for all fetal incisions. Using this combination of ketamine and local anesthesia, fetuses do not respond to surgical incisions. A hysterotomy was performed, and polyvinyl catheters were inserted into the pedal vein and artery and right brachial artery of the fetus and advanced into the inferior vena cava, descending aorta, and ascending aorta, respectively. A left thoracotomy was performed, and the left lung was retracted to expose the great vessels. Taking particular care to stay away from the ductus arteriosus, the following procedures were performed: ligation of the left hemizygous vein, placement of a mechanical snare (made from a polyvinyl-covered cardiac catheterization guide wire and a catheter sheath) around the left main pulmonary artery, direct placement of a $4 \mathrm{~F}$ Swan-Ganz balloon catheter (through a catheter sheath in the main pulmonary trunk) into the right pulmonary artery, and placement of a catheter in the main pulmonary trunk. The pulmonary catheter, snare, and balloon catheter were brought through the fetal chest wall, and the thoracotomy was closed. The fetus was given pancuronium bromide $(0.4 \mathrm{mg}$ intravenously) for paralysis and diazepam $(0.3$ $\mathrm{mg} / \mathrm{kg}$ intravenously) for sedation. The trachea was intubated with a $4.5 \mathrm{~F}$ cuffed endotracheal tube. The umbilical cord was ligated, and the lamb was delivered to a warming table and ventilated (in the prone position) with an infant ventilator. Through a peripheral cutdown in the neck (using local anesthesia), additional intravascular catheters were passed into the newborn lamb's left ventricle and superior vena cava, and an umbilical artery also was cannulated from the umbilical cord.

The initial ventilator settings were: PIP, $28 \mathrm{~cm}$ water; positive end expiratory pressure, $3 \mathrm{~cm}$ water; inspiratory time, $0.6 \mathrm{sec}$; and respiratory rate, 40 breaths/min. The initial $\mathrm{F}_{\mathrm{i}} \mathrm{O}_{2}$ was 1.0 . The $\mathrm{PaO}_{2}$ was maintained between 50 and 170 torr by adjusting the $\mathrm{F}_{\mathrm{i}} \mathrm{O}_{2}$; the $\mathrm{PaCO}_{2}$ was maintained between 25 and 40 torr by adjusting the PIP and respiratory rate. An intravenous infusion of $5 \%$ dextrose with $0.2 \mathrm{~N} \mathrm{NaCl}$ in water at a rate of $5 \mathrm{ml} / \mathrm{kg} / \mathrm{h}$ was begun after delivery. The lambs initially were towel-dried and covered with a plastic sheet to reduce evaporative losses. Rectal temperature was maintained between $38^{\circ}$ and $39^{\circ} \mathrm{C}$ with aquamatic K-pads and with radiant heat lamps. Heparinized placental blood was transfused to replace blood lost from sampling.

Descending $\mathrm{P}_{\mathrm{AO}}, \mathrm{P}_{\mathrm{pa}}$, and right atrial and left ventricular pressures were measured continuously using Beckman pressure transducers (Beckman Instruments, Inc., Fullerton, CA) and a Sensormedics Dynograph R611 multichannel recorder (Anaheim, $\mathrm{CA}$ ). The signals were averaged electronically to obtain mean pressures.

Although it would be desirable to measure phasic instantaneous blood flow across the ductus using a flow probe, this technique cannot be used accurately with the ductus because the contact with the probe changes as the ductus constricts; in addition, application of probes around the ductus will damage the underlying tissue and make later measurements of ductus contractility impossible. Therefore, we used the radioactive microsphere method $(8-10)$ to determine mean blood flows at particular time points. We injected three different radiolabeled $15 \mu \mathrm{m}$ microspheres (approximately $10^{6}$ of each) into the left ventricle, inferior vena cava, and superior vena cava whereas reference blood samples were withdrawn from the ascending and descending aorta $(8-10)$. Nine different microspheres were used: ${ }^{153} \mathrm{Gd},{ }^{57} \mathrm{Co},{ }^{114} \mathrm{In},{ }^{51} \mathrm{Cr},{ }^{113} \mathrm{Sn},{ }^{85} \mathrm{Sr},{ }^{95} \mathrm{Nb},{ }^{54} \mathrm{Mn}$, and ${ }^{65} \mathrm{Zn}$. After the experiment, the lamb was autopsied to check catheter placement and function of the mechanical snare and balloon catheter.
The organs were removed, weighed, and placed in formalin They were incinerated at $325^{\circ} \mathrm{C}$ for $72 \mathrm{~h}$, pulverized, and packed into counting vials. The amount of each radionuclide in the organs and the reference blood samples was measured with a well-type $\gamma$-scintillation counter and a multiple channel pulse height analyzer.

$\dot{Q}_{L V}$ and $\dot{Q}_{\text {ductus }} \mathrm{L} \rightarrow \mathrm{R}$ were calculated using the concentration of microspheres (that were injected into the left ventricle) in the reference samples, the total number of microspheres recovered from the whole animal, and the total number of microspheres in the lungs (8-10). In this study (see "Results"), we found that bronchial flow to the left lung (measurements made in the lambs in which the left pulmonary artery had been ligated) was only $0.6 \pm 0.3 \%$ (mean $\pm \mathrm{SD}, n=21$ measurements) of QLV. If we assume that bronchial blood flow to the left lung represents $1 / 3$ of the bronchial flow to the total lung, then the total bronchial flow was less than $2 \%$ of QLV. In comparison, the $\dot{Q}_{\text {ductus }} \mathrm{L} \rightarrow \mathrm{R}$-total was $30 \pm 3 \%$ of QLV during the first $4 \mathrm{~h}$ after delivery (see "Results," Figs. 1 and 2). Therefore, the bronchial flow makes up less than $10 \%$ of the $\dot{Q}_{\text {ductus }} \mathrm{L} \rightarrow \mathrm{R}$-total. Measurements of $\dot{\mathrm{Q} F O})$ and $\dot{\mathrm{Q}}_{\text {ductus }} \mathrm{R} \rightarrow \mathrm{L}$ were made using microspheres that were injected into the inferior and superior vena cava (9). Pulmonary blood flow was calculated as the sum of the venous return to the right atrium plus $\dot{\mathrm{Q}}_{\text {ductus }} \mathrm{L} \rightarrow \mathrm{R}$ minus $\left(\dot{\mathrm{Q}} \mathrm{FO}+\dot{\mathrm{Q}}_{\text {ductus }} \mathrm{R} \rightarrow \mathrm{L}\right.$ ) (9).

To compare relative degrees of ductus constriction in vivo, we estimated the average $R_{\text {ductus }}$ in the direction of the mean pressure gradient across the vessel (mean $\mathrm{P}_{\mathrm{AO}}$ minus mean $\mathrm{P}_{\mathrm{pa}}$ difference). Therefore, $R_{\text {ductus }}$ was calculated by dividing the mean $\mathrm{P}_{\mathrm{AO}}$ minus $\mathrm{P}_{\mathrm{pa}}$ difference by the appropriate ductus arteriosus flow (either $\mathrm{Q}_{\text {ductus }} \mathrm{L} \rightarrow \mathrm{R}$ or $\dot{\mathrm{Q}}_{\text {ductus }} \mathrm{R} \rightarrow \mathrm{L}$, depending on whether the pressure gradient was $\mathrm{L} \rightarrow \mathrm{R}$ or $\mathrm{R} \rightarrow \mathrm{L}$ ). This estimate assumes that there is laminar flow through the ductus, that mean pressure differences are an adequate reflection of the changes in driving pressure across the ductus during the cardiac cycle, and that net flow through the ductus is unidirectional. Because turbulence may develop at the pulmonic end of the ductus as it constricts, the pulmonary artery catheter was placed as far away from the ductus as possible (close to the pulmonary valve). If there were turbulent flow around the catheter, then just measuring the pressure drop across the ductus arteriosus would overestimate the change in driving energy across the vessel. This would lead to an overestimation of $R_{\text {ductus. }}$. This measurement of $R_{\text {ductus }}$ has been found to be a useful estimate of ductus constriction when flow through the ductus has been unidirectional from aorta to pulmonary artery $(8,11-13)$.

Arterial pH, $\mathrm{PaCO}_{2}$ and $\mathrm{PaO}_{2}$ were measured with a Corning 158 blood gas analyzer (Corning Medical and Scientific, Medfield, MA).

For $\mathrm{PGE}_{2}$ and 6 keto $\mathrm{PGF}_{1 \alpha}$ measurements, $10-\mathrm{ml}$ blood samples from pulmonary artery and descending aorta were withdrawn into chilled, heparinized tubes that contained indomethacin $(2 \mu \mathrm{g} / \mathrm{ml}$ blood $)$ and were centrifuged immediately at 2000 $\times g$ at $4^{\circ} \mathrm{C}$ for $30 \mathrm{~min}$. The procedures for extraction, chromatographic separation, and RIA of $\mathrm{PGE}_{2}$ and 6 keto $\mathrm{PGF}_{\mathrm{i} x}$ have been detailed previously $(11,12,14)$. In brief, $2 \mathrm{ml}$ of plasma were mixed with $2000 \mathrm{dpm}$ of ${ }^{3} \mathrm{H}-\mathrm{PGE}_{2}(130 \mathrm{Ci} / \mathrm{mmol}$, New England Nuclear, Boston, MA) or ${ }^{3} \mathrm{H}-6$ keto $\mathrm{PGF}_{1 \alpha}(110-130$ $\mathrm{Ci} / \mathrm{mmol}$, New England Nuclear) for calculation of recovery and acidified to $\mathrm{pH} 4.0$ with citric acid. The prostaglandins in the plasma samples were extracted with a cyclohexane:ethyl acetate (1:1) mixture for $\mathrm{PGE}_{2}$ or ethyl acetate alone for 6 keto $\mathrm{PGF}_{1 \alpha}$.

We measured $\mathrm{PGE}_{2}$ or 6 keto $\mathrm{PGF}_{1 \alpha}$ by RIA after their separation by silicic acid chromatography. For each concentration point of the standard curve for $\mathrm{PGE}_{2}$ or 6 keto $\mathrm{PGF}_{\mathrm{I} \alpha}$, we carried a 2-ml sample of lamb plasma, preincubated with activated charcoal to remove $\mathrm{PGE}_{2}$ or 6 keto $\mathrm{PGF}_{1 \alpha}$, through the purification process used for the 2-ml experimental plasma samples. Appropriate $\mathrm{PGE}_{2}$ or 6 keto $\mathrm{PGF}_{1 \alpha}$ standards were added to each of these evaporated residues. This procedure yielded reproducible standard curves with linear titration from $2.5-250$ 
pg $\mathrm{PGE}_{2}$ and $2.5-250 \mathrm{pg} 6$ keto $\mathrm{PGF}_{1 \alpha .}$. The cross reactivity of the antiserum to $\mathrm{PGE}_{2}$ (Institut Pasteur, Paris) and 6 keto $\mathrm{PGF}_{1 \alpha}$ (Advanced Magnetics, Inc., Cambridge, MA) have been described previously $(12,14)$. The recovery of ${ }^{3} \mathrm{H}-\mathrm{PGE}_{2}(50-60 \%)$ or ${ }^{3} \mathrm{H}-6$ keto $\mathrm{PGF}_{1 \alpha}(40-60 \%)$ was determined for each sample before RIA. Values were corrected for sample recovery.

Fifteen lambs were delivered and ventilated for $4 \mathrm{~h}$ after birth. Elevated main $\mathrm{P}_{\mathrm{pa}}$ was produced in seven lambs by totally occluding the left pulmonary artery (with the snare) and partially occluding the right pulmonary artery by inflating the balloon catheter. Within $15 \mathrm{~min}$ after delivery, the snare and balloon were manipulated to keep mean pulmonary blood pressure within 2-5 torr of $\mathrm{P}_{\mathrm{AO}}$. This was maintained for the next $4 \mathrm{~h}$. In eight control lambs, the left pulmonary artery snare was not tightened and the ballon was not inflated; there was a predictable drop in $\mathrm{P}_{\mathrm{pa}}$ after delivery in these animals. Hemodynamic and blood flow measurements were made at $1,2.5$, and $4 \mathrm{~h}$ after delivery. $\mathrm{PGE}_{2}$ and 6 keto $\mathrm{PGF}_{1 \mathrm{c}}$ were measured at 2 and $4 \mathrm{~h}$ after delivery.

Lamb ductus-in vitro. After completing the $4 \mathrm{~h}$ in vivo measurements, the lambs were killed rapidly by exsanguination. The ductus was dissected free from the loose adventitial tissue and divided into $1-\mathrm{mm}$ thick rings that were placed in separate 150-ml organ baths kept in the dark within an enclosed box. The rings were suspended between two stainless steel hooks in a modified Krebs-Tris solution at $38^{\circ} \mathrm{C}(11,15)$. Isometric responses of circumferential tension were measured by Grass FT03C force transducers (Grass Instrument Co., Quincy, MA) $(11,15)$.

Each of the rings was stretched to an initial length of 7-8 $\mathrm{mm}$. At this length, rings of ductus arteriosus have their maximal contractile response to increases in $\mathrm{PO}_{2}$ (15). Initially the $\mathrm{PO}_{2}$ of the bath solution was maintained at $20-25$ torr, and the rings were allowed to equilibrate for $45 \mathrm{~min}$ until a steady tension developed. The bath solution was then bubbled with $100 \% \mathrm{O}_{2}$ (to a $\mathrm{PO}_{2}$ of $680-700$ torr) until the tension achieved a new plateau. Indomethacin was added to the bath in a final concentration of $2 \mu \mathrm{g} / \mathrm{ml}\left(5.6 \times 10^{-6} \mathrm{M}\right)$, and the rings were allowed to achieve a new increase in tension over the next $h$. A cumulative dose response to $\mathrm{PGE}_{2}$ was obtained in the oxygen- and indomethacin-contracted rings; we allowed the tension to achieve a new plateau before higher concentrations of $\mathrm{PGE}_{2}$ were added. After the experiment, the tissues were removed from the baths and blotted dry so that their wet wt could be determined. The tension developed in the ring was expressed as force/crosssectional area $\left(\mathrm{g} / \mathrm{mm}^{2}\right)(15)$.

To measure $\mathrm{PGE}_{2}$ production by the isolated ductus arteriosus, $1 \mathrm{~mm}$ ductus rings from the same lambs were suspended (as described above) in 5-ml organ baths designed for the collection of the bath solution. The $5-\mathrm{ml}$ bath solution was changed every 40 min. Initially the bath solution was bubbled with $100 \% \mathrm{~N}_{2}$ for $80 \mathrm{~min}\left(\mathrm{PO}_{2}\right.$ : 26-32 torr) and the ring was allowed to equilibrate until a steady tension developed. The bath solution was then bubbled with $100 \% \mathrm{O}_{2}\left(\mathrm{PO}_{2}: 600-700\right.$ torr) for $80 \mathrm{~min}$. Indomethacin containing solution $\left(5.6 \times 10^{-6} \mathrm{M}\right)$ was then added while the rings were bubbled with $100 \% \mathrm{O}_{2}$ for another $80 \mathrm{~min}$. The $5 \mathrm{ml}$ bath solutions from the 40 - to 80 -min oxygen exposure and the 40- to 80-min oxygen-plus-indomethacin exposure were collected. extracted, purified, and assayed for $\mathrm{PGE}_{2}$ as described previously (11).

Indomethacin (Sigma Chemical Co., St. Louis, MO) was prepared in ethanol $(16 \mathrm{mg} / \mathrm{ml})$, and aliquots were added to the bath solution. $\mathrm{PGE}_{2}$ and 6 keto $\mathrm{PGF}_{1 \alpha}$, generously supplied by Dr. J. E. Pike of the Upjohn Co. (Kalamazoo, MI), were dissolved in ethanol before use. Concentrations of $\mathrm{PGE}_{2}$ and 6 keto $\mathrm{PGF}_{1 \kappa}$ are expressed as free acid concentrations. The protocol outlined above was approved by the Committee on Animal Research of the University of California, San Francisco.

Statistics. We compared measurements between control lambs and lambs with elevated $\mathrm{P}_{\mathrm{pa}}$ by an unpaired $t$-test, or Mann Whitney $U$ test where appropriate. The level of significance was $p<0.05$ (two tailed). The level of significance was adjusted for multiple comparisons of group means with a Bonferroni correction. The effect of elevated $\mathrm{P}_{\mathrm{pa}}$ on blood pressures, flows, and blood gases at various times after delivery was tested by twofactor (elevated blood pressure and age) ANOVA with replication. When a significant interaction between elevated pressures and time was found, the effect of elevated pressure was tested independently by an unpaired $t$-test. The data are reported as means \pm SD.

\section{RESULTS}

The effects of partial obstruction of branch pulmonary blood flow on blood pressures are depicted in Table 1 . In the control animals, the $\mathrm{P}_{\mathrm{pa}}$ rapidly dropped to $60 \%$ of $\mathrm{P}_{\mathrm{AO}}$ after delivery and remained at this level for the next $4 \mathrm{~h}$. In contrast, in the experimental animals with elevated $P_{p a}$, we were able to keep the $P_{p a}$ close to $P_{A O}$ during the $4 \mathrm{~h}$ after delivery. Lambs with mechanically elevated $\mathrm{P}_{\mathrm{pa}}$ had significantly greater $\mathrm{P}_{\mathrm{pa}}$ and significantly lower $\mathrm{P}_{\mathrm{AO}}$ than the control lambs at each measurement point. In addition, $\dot{Q}_{L V}$ and $\dot{Q}_{\text {pulm }}$ were significantly diminished in the lambs with elevated $\mathrm{P}_{\mathrm{pa}}$ (Fig. 1).

Despite the increase in main $\mathrm{P}_{\mathrm{pa}}$ in the mechanically obstructed group, there was no change in QFO when compared with controls (Fig. 2). Elevated $\mathrm{P}_{\mathrm{pa}}$ produced a small but significant increase in $\mathrm{Q}_{\text {ductus }} \mathrm{R} \rightarrow \mathrm{L}$ during the first $4 \mathrm{~h}$ after delivery (Fig. 2).

Lambs with mechanically elevated $P_{p a}$ had their left pulmonary arteries totally occluded. Therefore, microspheres from the left ventricular injection that lodged in the left lung represent the proportion of QLV that came through the bronchial circulation. This was only $0.6 \pm 0.3 \%$ of QLV. In these lambs, $98 \pm 2 \%(n=$ 21) of the microspheres injected into the left ventricle that were recovered in the lungs were found in the right lung and represent $\dot{Q}_{\text {ductus }} \mathrm{L} \rightarrow \mathrm{R}$. The left pulmonary artery was not occluded in the control lambs; in this group, $65 \pm 12 \%(n=24)$ of $\dot{\mathrm{Q}}_{\text {ductus }} \mathrm{L} \rightarrow \mathrm{R}$ was distributed to the right lung. Elevated $\mathrm{P}_{\mathrm{pa}}$ produced a significant decrease in the net left to right ductus shunt that was present during the first $4 \mathrm{~h}$ after delivery (Fig. 2).

We estimated the degree of ductus arteriosus constriction that occurred in vivo by calculating the $\mathrm{R}_{\text {ductus. }}$ Lambs in the control group had no net right to left flow and only a unidirectional left to right flow through their ductus. All lambs in the elevated $\mathrm{P}_{\mathrm{pa}}$ control group during the $4 \mathrm{~h}$ after delivery (Table 1). The in the elevated $P_{p a}$ group was significantly less than that in the control group during the $4 \mathrm{~h}$ after delivery (Table 1). The decreased amount of ductus constriction in the lambs with elevated main $\mathrm{P}_{\text {pa }}$ pressure could not be accounted for by differences in arterial blood gases (Fig. 3) or by differences in circulating concentrations of $\mathrm{PGE}_{2}$ or 6 keto $\mathrm{PGF}_{1 \alpha}$ (Table 2).

At the end of $4 \mathrm{~h}$, the animals were killed to see how the effects of elevated main $\mathrm{P}_{\mathrm{pa}}$ and decreased ductus arteriosus constriction in vivo altered the responsiveness of the ductus in vitro. When the ductus was removed from the lamb and cut in cross-section, we found that, in the lambs with elevated main $P_{p a}$, lumen diameter was greater than $2 \mathrm{~mm}$, whereas the diameter in control lambs was less than $2 \mathrm{~mm}$. This finding is consistent with our in vivo measurements of $\mathrm{R}_{\text {ductus. }}$.

As we have previously found, a ductus isolated from a near term control lamb, in which there was a significant drop in $\mathrm{P}_{\mathrm{pa}}$ and constriction of the ductus after delivery, could generate only a small fraction of the active tension (induced by oxygen and indomethacin) of that generated by a ductus isolated from the near term fetus (Table 3, compare with values reported in Refs. 13 and 16). In addition, $\mathrm{PGE}_{2}$ was not as effective in relaxing the ductus from our near term control lambs as it was in relaxing the ductus from near term fetal lambs (Table 3, compare with values reported in Refs. 13 and 16). 
Table 1. Effect of mechanical obstruction of branch pulmonary arteries on blood pressures, HR, and $R_{\text {ductus }}{ }^{*}$

\begin{tabular}{|c|c|c|c|c|c|c|}
\hline \multirow[b]{2}{*}{ Time after delivery $(\mathrm{h})$} & \multicolumn{3}{|c|}{ Control $(n=8)$} & \multicolumn{3}{|c|}{ Increased $\mathrm{P}_{\mathrm{pa}}(n=7)$} \\
\hline & 1 & 2.5 & 4 & 1 & 2.5 & 4 \\
\hline$\overline{\mathrm{P}}_{\mathrm{AO}}$ & $71 \pm 10 \dagger$ & $78 \pm 7 \$$ & $77 \pm 8 \ddagger$ & $57 \pm 10$ & $65 \pm 8$ & $62 \pm 8$ \\
\hline$\overline{\mathrm{P}}_{\mathrm{pa}}$ & $44 \pm 14 \S$ & $43 \pm 15 \ddagger$ & $46 \pm 16 \div$ & $56 \pm 11$ & $65 \pm 9$ & $63 \pm 8$ \\
\hline$\overline{\mathrm{P}}_{\mathrm{SVC}}$ & $2 \pm 1$ & $2 \pm 1$ & $2 \pm 1$ & $3 \pm 1$ & $3 \pm 1$ & $3 \pm 1$ \\
\hline$P_{\text {LVED }}$ & $6 \pm 3$ & $4 \pm 2$ & $4 \pm 3$ & $5 \pm 1$ & $4 \pm 1$ & $4 \pm 1$ \\
\hline HR (beats. $\min ^{-1}$ ) & $204 \pm 34$ & $200 \pm 39$ & $201 \pm 36$ & $174 \pm 48$ & $168 \pm 23$ & $188 \pm 39$ \\
\hline $\mathrm{R}_{\text {ductus }}$ (torr $\cdot \min ^{-1} \cdot \min \cdot \mathrm{kg}$ ) & $0.42 \pm 0.24 \dagger$ & $0.46 \pm 0.24 \ddagger$ & $0.35 \pm 0.14 \S$ & $0.10 \pm 0.15$ & $0.08 \pm 0.06$ & $0.16 \pm 0.24$ \\
\hline
\end{tabular}

$*$ Values are mean $\pm \mathrm{SD}$.

$\dagger p<0.02$ for differences between control and increased $\mathrm{P}_{\mathrm{pa}}$ groups.

$\ddagger p<0.005$ for differences between control and increased $\mathrm{P}_{\mathrm{pa}}$ groups.

$\S p<0.05$ for differences between control and increased $P_{p a}$ groups.
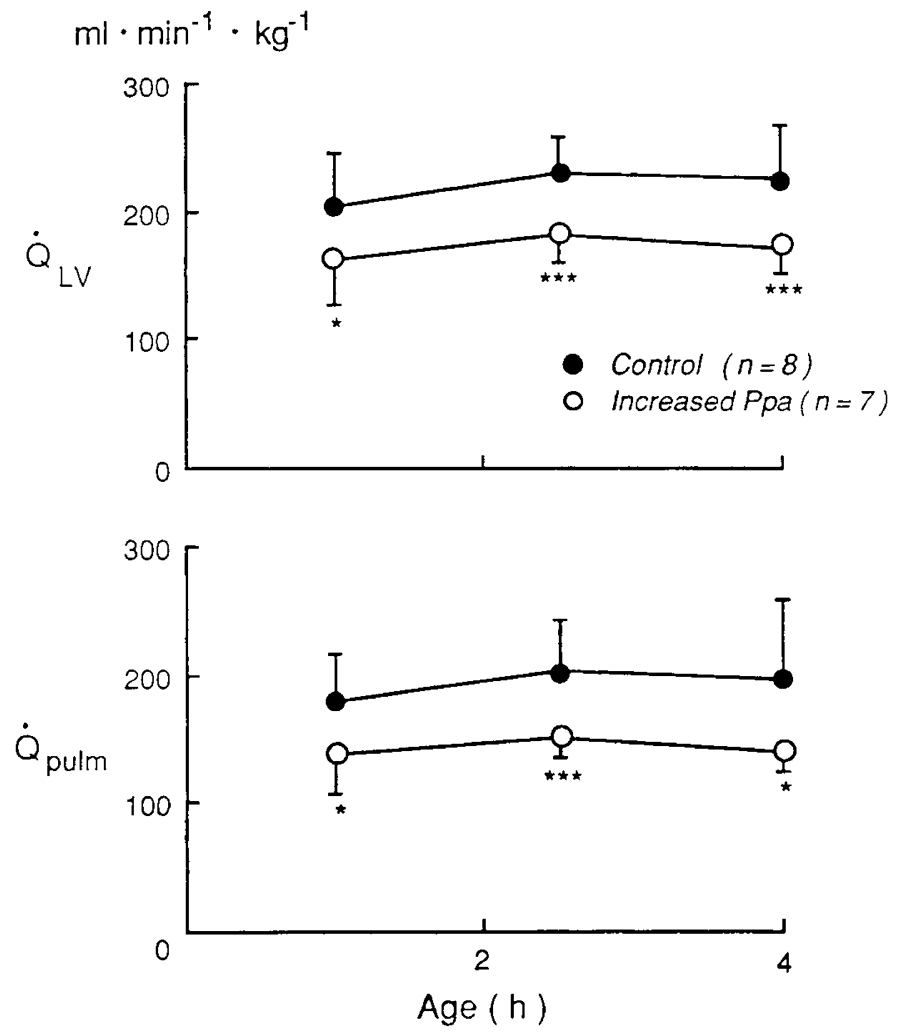

Fig. 1. Effect of mechanical obstruction of branch pulmonary arteries on Q $L V$ and Q Pulm. Values are mean $\pm \mathrm{SD} .{ }^{*} P<0.05,{ }^{* *} p<0.01$, $* * * p<0.005$ for differences between control and increased $\left(\mathrm{P}_{\mathrm{pa}}\right)$ groups.

In contrast, both the ability to contract actively (to either oxygen or indomethacin) as well as to actively relax (to $\mathrm{PGE}_{2}$ ) was significantly greater in the ductus arteriosus of lambs with elevated $\mathrm{P}_{\mathrm{pa}}$ (Table 3 ). There was little alteration of the ability of $\mathrm{PGE}_{2}$ to relax the ductus isolated from lambs with elevated $\mathrm{P}_{\mathrm{pa}}$ (and delayed ductus constriction in vivo) when compared with the ductus from fetal lambs (Table 3). The ductus from lambs with elevated $P_{p a}$ was more than twice as sensitive to $\mathrm{PGE}_{2}$ than was the ductus from control lambs. Similarly, after the same length of postnatal ventilation, the ductus from lambs with elevated pulmonary blood pressure retained more than twice the contractile activity (to either oxygen or indomethacin) as the ductus from the control lambs with reduced $\mathrm{P}_{\mathrm{pa}}$.

This difference in contractile behavior of the isolated ductus could not be accounted for by differences in endogenous $\mathrm{PGE}_{2}$ production. The ductus from both control lambs and those with elevated $\mathrm{P}_{\mathrm{pa}}$ produced similar amounts of $\mathrm{PGE}_{2}$ when exposed to oxygen; their $\mathrm{PGE}_{2}$ production rate was inhibited to the same extent when they were exposed to indomethacin (Fig. 4).

\section{DISCUSSION}

These studies were performed in acutely prepared, sedated, and paralyzed neonatal lambs; extrapolating the results to the normal birth situation should be done with caution. With this caveat in mind, we found that both control lambs and those with obstructed branch pulmonary arteries were hemodynamically stable during the $4 \mathrm{~h}$ after delivery. Lambs with obstructed pulmonary arteries had significantly lower $\dot{Q}_{\text {pulm }}$, left ventricular output, and $\mathrm{P}_{\mathrm{AO}}$ than control lambs. The decrease in $\mathrm{P}_{\mathrm{AO}}$ and QLV probably is a reflection of the drop in right ventricular output caused by the marked increase in right ventricular afterload (17). Lambs with obstructed pulmonary arteries also required greater ambient oxygen and greater ventilator pressures and rates to maintain their blood gases in the same range as the control lambs. The blood gas alterations in the lambs with obstructed pulmonary arteries are not surprising when one considers: 1) the increased ratio of $\dot{\mathrm{Q} F O}$ and $\dot{\mathrm{Q}}_{\text {ductus }} \mathrm{R} \rightarrow \mathrm{L}$ compared to QLV (17\% of QLv versus $12 \%$ in control lambs), 2) the decreased total $P_{p a}$, and 3 ) the decreased recirculation through the lungs of oxygenated blood from the left to right ductus shunt $(18,19)$.

Although the mechanisms that regulate patency and closure of the ductus arteriosus are only partially understood, most attention has been paid to the factors that directly alter ductal tone (1). There appears to be a balance between the constricting effect of oxygen and the vasodilating effect of the prostaglandins $E_{2}$ and $I_{2}$. The marked sensitivity of the lamb ductus to $P E_{2}$ suggests that this is the most important prostanoid for regulation of vessel patency in this species (1). Despite similar circulating concentrations of $\mathrm{PaO}_{2}, \mathrm{PGE}_{2}$, and 6 keto $\mathrm{PGF}_{1 \alpha}$ (a stable metabolite of $\mathrm{PGI}_{2}$ ) (Fig. 3; Table 2) and similar rates of endogenous $\mathrm{PGE}_{2}$ production (Fig. 4), we found decreased ductus constriction (using our estimate of $R_{\text {ductus }}$ ) in the lambs with elevated main $P_{p a}$ (Table 1). Elevated intravascular pressure could affect ductus arteriosus caliber in several ways. First, for a given stimulus for equal-sized vessels, vasoconstriction would be inhibited in the vessel with the greater luminal pressure. Second, as resting wall tension is passively increased by elevated luminal pressure, the potential for additional active increases in tension may be significantly reduced (15). Our findings have parallels in the pulmonary vascular bed where changes in vascular pressure have a passive effect on vascular caliber (20). An increase in vascular pressure has been found to diminish the response of the pulmonary bed to both hypoxic (21) and nonhypoxic (22) stimuli.

Previously we have found that when the ductus arteriosus is removed from the neonatal lamb several $h$ after delivery and studied in vitro, it has lost much of its ability to dilate or contract to vasoactive stimuli (13). This generalized loss of ductus respon- 


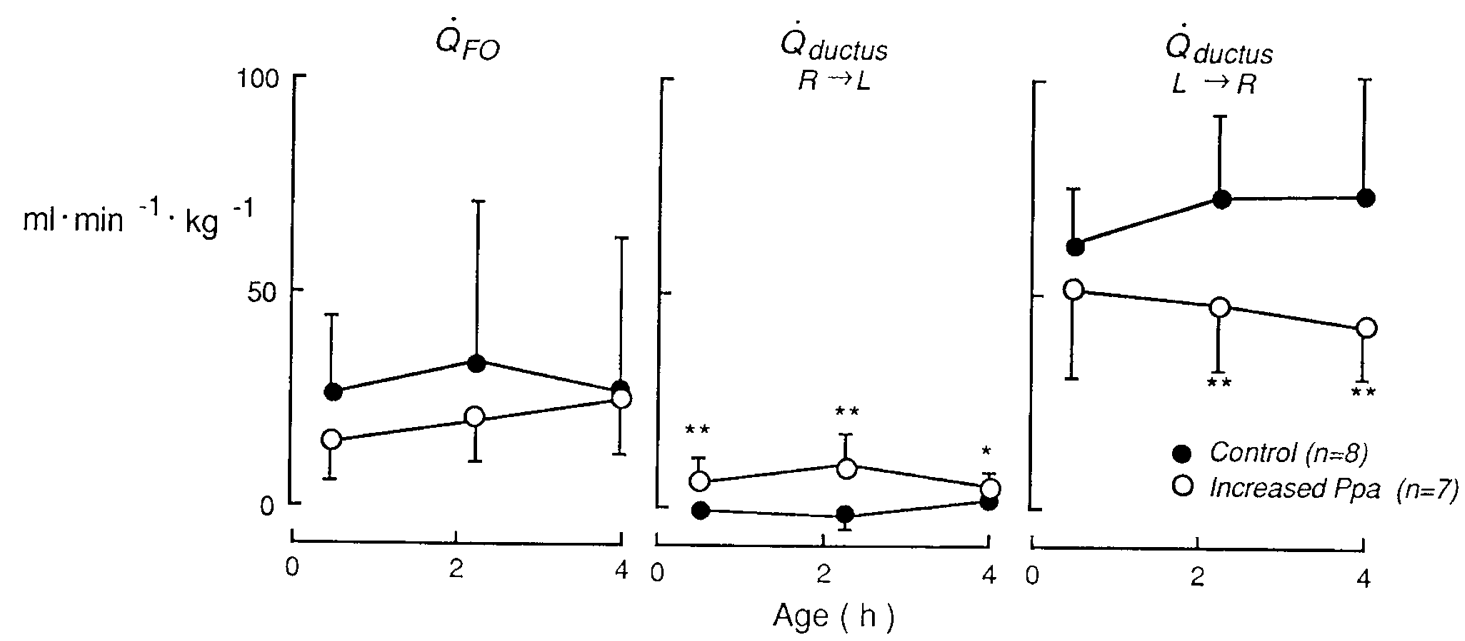

Fig. 2. Effect of mechanical obstruction of branch pulmonary arteries on $\dot{\mathrm{Q} F O}$ and the $\dot{\mathrm{Q}}_{\text {ductus }} \mathrm{R} \rightarrow \mathrm{L}$, and $\dot{\mathrm{Q}}_{\text {ductus }} \mathrm{L} \rightarrow \mathrm{R}$. Values are mean \pm SD. ${ }^{*} p<0.005,{ }^{* *} p<0.025$ for differences between control and increased Ppa groups.

- Control $(n=8)$ - Increased Ppa

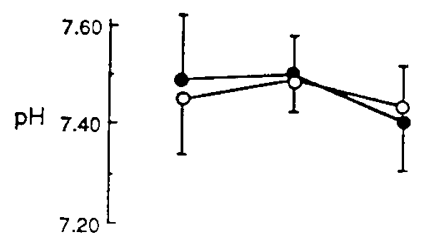<smiles>O=C(O)C1CCCC1C(=O)O</smiles>

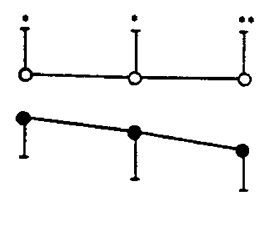

$\mathrm{PaO}^{180} \mathrm{O}_{2}$

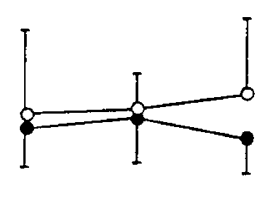

$\mathrm{Cm} \mathrm{H}_{2} \mathrm{O}_{10}^{20}$
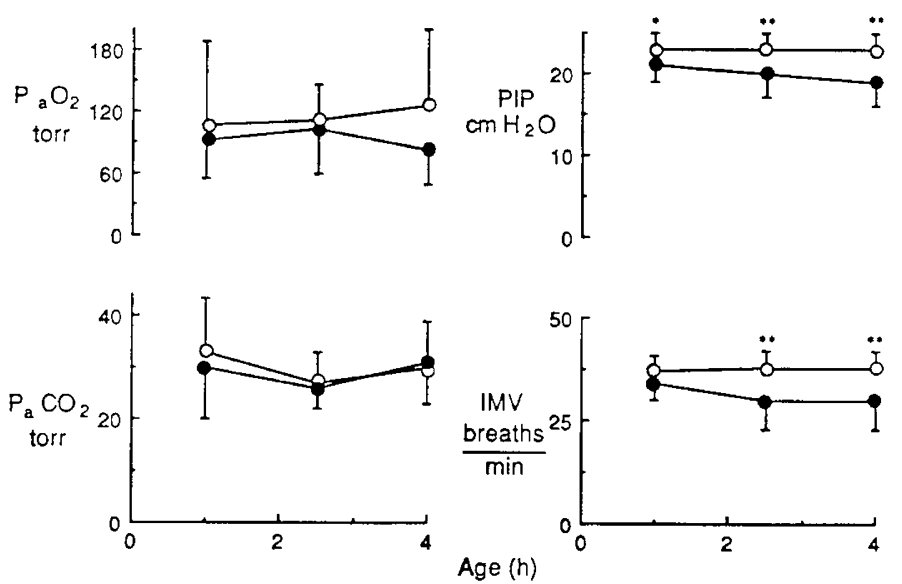

Fig. 3. Effect of mechanical obstruction of branch pulmonary arteries on the $\mathrm{F}_{i} \mathrm{O}_{2}$, PIP, and IMV needed to keep pH, $\mathrm{PaO}_{2}$, and $\mathrm{PaCO}_{2}$ in a defined range. Values are mean $\pm \mathrm{SD} .{ }^{*} p<0.05$, ${ }^{* *} p<0.01$ for differences between control and increased Ppa groups.

siveness was directly related to the degree of prior ductus constriction and to the subsequent reduction in lumen diameter in vivo. The loss of responsiveness was independent of arterial $\mathrm{PaO}_{2}$, $\mathrm{pH}$, and $\mathrm{PGE}_{2}$ concentrations. In addition, this loss of responsiveness prevented the ductus arteriosus from reopening once it had constricted (13). This functional change probably reflects early ischemic damage to the inner muscle wall. In the normal newborn lamb, the increased $\mathrm{PaO}_{2}$ and drop in circulating $\mathrm{PGE}_{2}$ after delivery stimulate ductus arteriosus constriction (1). As the ductus constricts, intraluminal pressure drops on the pulmonary side due to the drop in pulmonary vascular resistance after birth (23). As pressure decreases on the pulmonary end of the ductus, less muscle tension is needed to overcome the transmural pressure at that end and to continue the progressive constriction. In addition, as the ductus constricts, there may be increased velocity
Table 2. Effect of mechanical obstruction of branch pulmonary arteries on the circulating concentrations of $P G E_{2}$ and 6 keto

\begin{tabular}{|c|c|c|c|c|}
\hline \multirow{2}{*}{$\begin{array}{l}\text { Time after delivery } \\
(\mathrm{h})\end{array}$} & \multicolumn{2}{|c|}{ Aorta } & \multicolumn{2}{|c|}{ Pulmonary artery } \\
\hline & 2 & 4 & 2 & 4 \\
\hline \multicolumn{5}{|l|}{$\mathrm{PGE}_{2}(\mathrm{pg} / \mathrm{ml})$} \\
\hline Control & $\begin{array}{c}91 \\
(1-286)\end{array}$ & $\begin{array}{c}57 \\
(1-271)\end{array}$ & $\begin{array}{c}54 \\
(1-68)\end{array}$ & $\begin{array}{c}38 \\
(1-41)\end{array}$ \\
\hline Increased $\mathrm{P}_{\mathrm{pa}}$ & $\begin{array}{c}62 \\
(1-86)\end{array}$ & $\begin{array}{c}25 \\
(1-49)\end{array}$ & $\begin{array}{c}66 \\
(1-163)\end{array}$ & $\begin{array}{c}27 \\
(1-72)\end{array}$ \\
\hline \multicolumn{5}{|l|}{6 keto $\mathrm{PGF}_{1 \alpha}(\mathrm{pg} / \mathrm{ml})$} \\
\hline Control & $\begin{array}{c}16 \\
(2-1010)\end{array}$ & $\begin{array}{c}15 \\
(2-499)\end{array}$ & $\begin{array}{c}9 \\
(3-364)\end{array}$ & $\begin{array}{c}9 \\
(4-328)\end{array}$ \\
\hline Increased $\mathrm{P}_{\mathrm{pa}}$ & $\begin{array}{c}3 \\
(2-448)\end{array}$ & $\begin{array}{c}3 \\
(2-20)\end{array}$ & $\begin{array}{c}5 \\
(2-206)\end{array}$ & $\begin{array}{c}5 \\
(2-223)\end{array}$ \\
\hline
\end{tabular}

* Values are median (range). Control group $(n=8)$; increased $\mathrm{P}_{\mathrm{pa}}$ group $(n=7)$. There were no differences between control and increased $\mathrm{P}_{\mathrm{pa}}$ groups that reached a level of significance $<0.05$.

of red blood cell flow through the closing lumen. As a result there would be less potential energy stretching the vessel walls and therefore less intraluminal pressure to oppose constriction. However, as the ductus constricts it develops ischemic damage and becomes less capable of responding to vasoactive stimuli. How does the ductus remain closed once it has suffered ischemic damage? One may infer from the law of Laplace that as a vessel constricts, greater intravascular pressures will be required to cause any subsequent increase in vessel diameter. Mathematical considerations suggest that there is a critical closing pressure below which the lumen of a vessel will be obliterated (24-26). It would therefore follow that once the ductus is constricted, it may be kept constricted by very little muscular effort (25).

In contrast, in newborn animals with persistently elevated pulmonary vascular resistance after delivery, initial constriction of the ductus and separation of the systemic and pulmonary circulations would not produce a drop in blood pressure on the pulmonary side of the ductus. The elevated $\mathrm{P}_{\mathrm{pa}}$ would continue to oppose vessel constriction. Because the normal loss of ductus responsiveness to vasoactive stimuli appears to be due to the degree of postnatal ductus constriction, one would expect that the ductus from lambs with postnatal pulmonary hypertension would continue to have a fetal pattern of vasoactive responsiveness. In the present study, there was a reduced rate of ductus closure (in vivo) during the first $4 \mathrm{~h}$ after delivery in the lambs with elevated pulmonary blood pressure. Consistent with our 
Table 3. In vitro behavior of ductus arteriosus taken from fetal lambs, newborn control lambs, and newborn lambs with elevated $P_{p a}{ }^{*}$

\begin{tabular}{|c|c|c|c|c|c|c|}
\hline & \multicolumn{3}{|c|}{ Active tension } & \multicolumn{3}{|c|}{$\mathrm{PGE}_{2}$ inhibition of tension } \\
\hline & $\begin{array}{c}\mathrm{O}_{2} \\
\left(\mathrm{~g} / \mathrm{mm}^{2}\right) \\
\end{array}$ & $\begin{array}{c}\text { Indomethacin } \\
\left(\mathrm{g} / \mathrm{mm}^{2}\right)\end{array}$ & $\begin{array}{c}\mathrm{O}_{2}+\text { indomethacin } \\
\left(\mathrm{g} / \mathrm{mm}^{2}\right)\end{array}$ & $\begin{array}{l}\text { Threshold } \\
(\mathrm{pg} / \mathrm{ml})\end{array}$ & $\begin{array}{c}\mathrm{ED}_{50} \\
(\mathrm{pg} / \mathrm{ml}) \\
\end{array}$ & $\begin{array}{l}\text { Maximum } \\
(\%) \\
\end{array}$ \\
\hline Fetal $\dagger$ & & & $4.24 \pm 1.39$ & & $448 \pm 389$ & $73 \pm 25$ \\
\hline Control & $1.17 \pm 0.59$ & $0.28 \pm 0.09$ & $1.45 \pm 0.63$ & $535 \pm 508$ & $1491 \pm 772$ & $28 \pm 18$ \\
\hline Increased $\mathrm{P}_{\mathrm{pa}}$ & $2.98 \pm 1.72 \ddagger$ & $0.66 \pm 0.25 \S$ & $3.63 \pm 0.65 \S$ & $165 \pm 224 \|$ & $666 \pm 475 \ddagger$ & $63 \pm 32 \ddagger$ \\
\hline
\end{tabular}

* Values are mean $\pm \mathrm{SD}$. First, each ring $\left(22.7 \pm 5.4 \mathrm{mg}\right.$ wet wt) was allowed to equilibrate in a low $\mathrm{PO}_{2}$ environment; steady state tensions, which were produced by the ring when incubated in a low $\mathrm{PO}_{2}$ environment were: control group $=2.17 \pm 1.15 \mathrm{~g} / \mathrm{mm}^{2}(n=8)$; increased $\mathrm{P}_{\mathrm{pa}}$ group $=2.68$ $\pm 1.07 \mathrm{~g} / \mathrm{mm}^{2}(n=7)$. The active tension for oxygen is the difference between the steady state tension at low $\mathrm{PO}_{2}$ and the tension after the rings had contracted with high $\mathrm{PO}_{2}$; active tension for indomethacin is the difference between the steady state tension in high $\mathrm{O}_{2}$ and high $\mathrm{O}_{2}$ plus indomethacin; active tension for $\mathrm{O}_{2}+$ indomethacin is the difference between the steady state tension in high $\mathrm{O}_{2}$ plus indomethacin and the tension at low $\mathrm{PO}_{2}$. $\mathrm{PGE}_{2}$ inhibition of tension is expressed for the active $\mathrm{O}_{2}+$ indomethacin tension. Threshold concentration is the lowest concentration of $\mathrm{PGE}_{2}$ needed to produce a significant decrease in tension. $\mathrm{ED}_{50}$ is the effective concentration of $\mathrm{PGE}_{2}$ that will produce $50 \%$ of the maximum $\mathrm{PGE}$ relaxation. Maximum relaxation is expressed as the percentage of inhibition of the active $\mathrm{O}_{2}+$ indomethacin tension.

+ Values for the ductus from fetal lambs were obtained from 10 near term fetuses ( $137 \pm 1$ days gestation) that were delivered by cesarean section and killed before their first breath (values were obtained from Ref. 13).

$\ddagger p<0.01$ for differences between control and increased $\mathrm{P}_{\mathrm{pa}}$ groups.

$\S p<0.005$ for differences between control and increased $\mathrm{P}_{\mathrm{pa}}$ groups.

$\| p<0.05$ for differences between control and increased $\mathrm{P}_{\mathrm{pa}}$ groups.

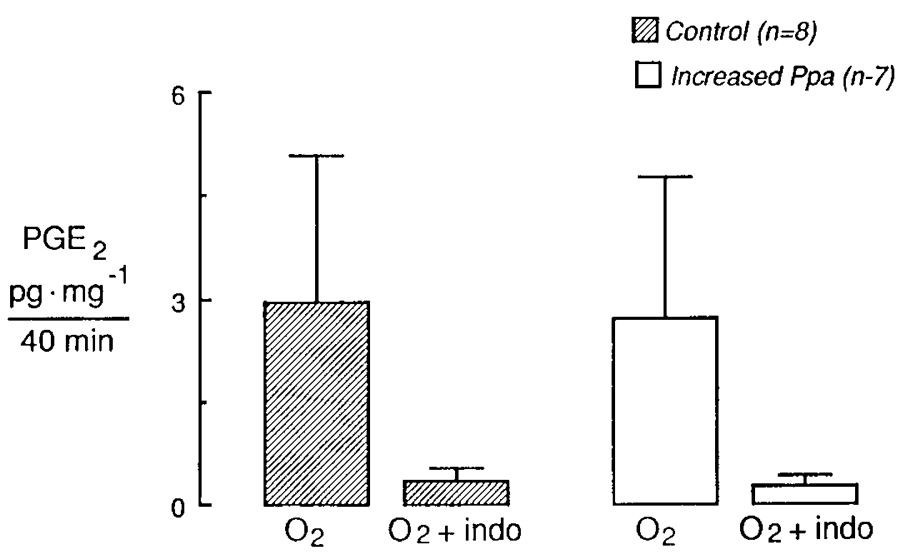

Fig. 4. Effect of mechanical obstruction of branch pulmonary arteries on the ability of isolated rings of ductus arteriosus to produce $\mathrm{PGE}_{2}$. Values are mean $\pm \mathrm{SD}$. First, all rings $(35.6 \pm 14.7 \mathrm{mg})$ were allowed to equilibrate in a low $\mathrm{PO}_{2}$ environment. Steady state low $\mathrm{PO}_{2}$ tensions were: control group $=2.42 \pm 0.73 \mathrm{~g} / \mathrm{mm}^{2}(n=8)$, increased Ppa group $=2.78$ $\pm 0.95 \mathrm{~g} / \mathrm{mm}^{2}(n=7)$. The bath solution was then bubbled with $100 \%$ $\mathrm{O}_{2}$. The $\mathrm{PGE}_{2}$ released by the rings between $40-80 \mathrm{~min}$ of exposure to $\mathrm{O}_{2}$ was measured. The rings were then exposed to indomethacin $2 \mu \mathrm{g} /$ $\mathrm{ml}\left(5.6 \times 10^{-6} \mathrm{M}\right)$. The $\mathrm{PGE}_{2}$ released by the rings between $40-80 \mathrm{~min}$ of exposure to indomethacin was measured. Indomethacin inhibited $\mathrm{PGE}_{2}$ released from the rings by $90 \%$. There were no differences between the two groups.

expectations, the ductus from lambs with elevated pulmonary pressures were still responsive to oxygen and $\mathrm{PGE}_{2}$ and behaved more like the ductus from fetal lambs than the ductus from newborn lambs with reduced pulmonary blood pressures. These findings in newborn lambs may help to explain both the increased incidence of PDA in full term infants with respiratory failure and pulmonary hypertension $(5,6)$ and the persistent responsiveness of the ductus in these infants once the increased pulmonary vascular resistance has been removed (7). In addition, this study supports the hypothesis that the normal drop in pulmonary vascular resistance and pressure that occurs in full term infants after delivery may facilitate the closure of the ductus arteriosus.

Acknowledgments. We thank Mr. Carl McWatters and Mr. Bruce Payne for their help with the microsphere data analysis,
Mr. Paul Sagan for his skill in preparing and editing this manuscript, Dr. David Teitel for helpful discussions about blood flow calculations, and Dr. A. M. Rudolph for his encouragement during the project.

\section{REFERENCES}

1. Clyman RI 1987 Ductus arteriosus: current theories of prenatal and postnatal regulation. Semin Perinatol 11:64-71

2. Heymann MA, Rudolph AM 1976 Effects of acetylsalicylic acid on the ductus arteriosus and circulation in fetal lambs in utero. Circ Res 38:418-422

3. Friedman WF, Printz MP, Kirkpatrick SE, Hoskins EJ 1983 The vasoactivity of the fetal lamb ductus arteriosus studied in utero. Pediatr Res 17:331-337

4. Smallhorn JF, Gow R, Olley PM, Freedom RM, Swyer PR, Perlman M, Rowe RD 1984 Combined noninvasive assessment of the patent ductus arteriosus in the preterm infant before and after indomethacin treatment. Am J Cardiol 54:1300-1304

5. Lotze A, Short BL, Taylor GA 1987 Lung compliance as a measure of lung function in newborns with respiratory failure requiring extracorporeal membrane oxygenation. Crit Care Med 15:226-229

6. Hall JA, Hartenberg MA, Kodroff MB 1985 Chest radiographic findings in neonates on extracorporeal membrane oxygenation. Radiology 157:75-77

7. Martin GR, Short BL 1988 Echo-Doppler evaluation of extracorporeal membrane oxygenation in infants. Pediatr Res 23(suppl):435 (abstr)

8. Clyman RI, Roman C, Heymann MA, Mauray F 1987 How a patent ductus arteriosus effects the premature lamb's ability to handle additional volume loads. Pediatr Res 22:531-535

9. Teitel DF, Iwamoto HS, Rudolph AM 1987 Effects of birth related events on central blood flow patterns. Pediatr Res 22:557-66

10. Heymann MA, Creasy RK, Rudolph AM 1973 Quantitation of blood flow pattern in the foetal lamb in utero. In: Proceedings of the Sir Joseph Barcroft Centenary Symposium: Foetal and Neonatal Physiology. Cambridge University Press, Cambridge, pp 129-135

11. Clyman RI, Jobe A, Heymann MA, Ikegami M, Roman C, Payne B, Mauray F 1982 Increased shunt through the patent ductus arteriosus after surfactant replacement therapy. J Pediatr 100:101-107

12. Clyman RI, Mauray F, Roman C, Heymann MA, Ballard PL, Rudolph AM, Payne B 1981 Effects of antenatal glucocorticoid administration on ductus arteriosus of preterm lambs. Am J Physiol 251:H415-H420

13. Clyman RI, Mauray F, Roman C, Heymann MA, Payne B 1983 Factors determining the loss of ductus arteriosus responsiveness to prostaglandin $\mathrm{E}$. Circulation 68:433-436

14. Teague WG Jr., Raj JU, Braun D, Berner ME, Clyman RI, Bland RD 1987 Lung vascular effects of lipid infusion in awake lambs. Pediatr Res 22:714 719

15. Clyman RI, Mauray F, Wong L, Heymann MA, Rudolph AM 1978 The developmental response of the ductus arteriosus to oxygen. Biol Neonate 34:177 -182

16. Clyman RI, Campbell D, Heymann MA, Mauray F 1985 Persistent responsiveness of the neonatal ductus arteriosus in immature lambs: a possible cause for reopening of patent ductus arteriosus after indomethacin-induced closure. Circulation 71:141-145

17. Thornburg KL, Morton MJ 1983 Filling and arterial pressures as determinants of RV stroke volume in the sheep fetus. Am J Physiol 244:H656-H663

18. Born GVR, Dawes GS, Mott JC, Rennick BR 1955 The relief of central cyanosis caused by pulmonary arteriovenous shunts by constriction of an 
artificial ductus arteriosus. J Physiol 130:167-190

19. West JB 1977 State of the art: ventilation-perfusion relationships. Am Rev Respir Dis 116:919-943

20. Borst HG, McGregor M, Whittenberger JL, Berglund E 1956 Influence of pulmonary arterial and left atrial pressures on pulmonary vascular resistance. Circ Res 4:393-399

21. Beaumof JL, Wahrenbrock EA 1975 Blunted hypoxic pulmonary vasoconstriction by increased lung vascular pressures. J Appl Physiol 38:846-850

22. Haas F, Bergofsky GH 1968 Effect of pulmonary vasoconstriction on balance between alveolar ventilation and perfusion. J Appl Physiol 24:491-497
23. Clyman RI, Mauray F, Heymann MA, Roman C 1987 Cardiovascular effects of a patent ductus arteriosus in preterm lambs with respiratory distress. $J$ Pediatr 111:579-587

24. Burton AC 1951 On the physical equilibrium of small blood vessels. Am Physiol 164:319-329

25. McIntyre TW 1969 An analysis of critical closure in the isolated ductus arteriosus. Biophys J 9:685-699

26. Nichol J, Girling F, Jerrard W, Claxton EB, Burton AC 1951 Fundamental instability of small blood vessels and critical closing pressures in vascular beds. Am J Physiol 164:330-344

\section{Announcements}

\section{Annual Meetings}

The American Pediatric Society, the Society for Pediatric Research, and the Ambulatory Pediatric Association will have meetings on May 1-5, 1989 at the Washington Sheraton Hotel, Washington; D.C.

Contact: SPR-Ms. Debbie Wogenrich, 2650 Yale Blvd., S.E., Suite 104, Albuquerque, NM 87106 (505)764-9099. APS-Dr. Audrey K. Brown, Secretary-Treasurer, Department of Pediatrics, SUNY, Health Science Center at Brooklyn, 450 Clarkson Avenue, Box 49, Brooklyn, NY 11203 (718)270-1692. APA-Ambulatory Pediatric Association, 6728 Old McLean Village, McLean, VA 22101 (703)556-9222.

\section{Symposium on Developmental Endocrinology}

A two-day symposium on Developmental Endocrinology sponsored by Ares-Serono Symposia will be held October 23-24, 1989, at the Hotel PENTA, Geneva, Switzerland. Three different sessions will cover new trends on Fetal and Neonatal Endocrinology, Puberty, and new aspects of the Biology and the Molecular Biology of Growth and Development.

This symposium is dedicated to Drs. Selna L. Kaplan and Melvin M. Grumbach.

For further information, please contact: Dr. P.C. Sizonenko/Dr. M.L. Aubert, Clinique de Pédiatrie, Hôpital Cantonal Universitaire, 30 Bd de la Cluse, CH-1211 Geneva 4, Switzerland, or Dr. S. Rossetti, Ares-Serono Symposia, Via Ravenna 8, I-00161 Rome Italy.

\section{Symposium on Pediatric Neuro-Oncology}

The premiere session of the International Symposium on Pediatric Neuro-Oncology is June 1-3, 1989, in Seattle, Washington.

The Symposium is sponsored by Children's Hospital \& Medical Center, Seattle, Children's Hospital of Philadelphia, and University of Washington School of Medicine.

For program information, contact CME, SC-50, University of Washington, Seattle, Washington 98195.

Poster and oral presentations are invited; for abstract form, due February 15, contact Dr. Bleyer at (206) 526-2107 or Fax 206-527-3838.

\section{Fetal and Neonatal Physiology}

International Union of Physiological Sciences satellite symposium "Fetal and Neonatal Physiology," Karolinska Institute, Stockholm, Sweden, July 5-8, 1989.

The meeting will include symposia and poster sessions on fetal growth, neuromodulators during development, perinatal neuroendocrinology, and water and electrolyte transport. Keynote lectures will focus on molecular biology in perinatal medicine, neonatal thermogenesis, lung maturation, asphyxia, and prostaglandins.

For information write: Dr. Hugo Lagercrantz, Neonatal Research Unit, Karolinska Institute, Box 60400, S-104 01 Stockholm, Sweden.

\section{Annual Meeting of the European Society for Pediatric Research}

The Annual Meeting of the European Society for Pediatric Research will be held in Kraków, Poland, June 11-14, 1989. In addition to free paper and poster sessions, plenary sessions and workshops will be held on topics including acute renal failure, advances in genetics and immunology, applied genetics, perinatal epidemiology, neonatology, diabetes, and atrial natriuretic peptides. European Working Groups on Allergy and Clinical Immunology, Mineral Metabolism, Neonatology, and Perinatal and Pediatric Microcirculation will participate. Deadline for receipt of abstracts will be January $31,1989$.

For abstract forms and information, contact the President of the Meeting: Jacek J. Pietrzyk, 1st Department of Pediatrics, Institute of Pediatrics, 30-663 Kraków, Wielicka 265, Poland, phone 55-02-56, telex 032-5795 IP AM PL.

\section{European Chief Editor}

Since the term of European Chief Editor Dr. Kari O. Raivio will expire at the end of 1989, the position of European Chief Editor of Pediatric Research will be open.

Duties include evaluation and editorial decisions regarding European manuscripts and collaboration with the Editor-in-Chief and the Board of Trustees of the International Pediatric Research foundation toward developing the journal scientifically. Financial support for the office is provided.

Interested applicants should submit a curriculum vitae and the names of at least four local editors from different fields of pediatrics who would help evaluate manuscripts. Inquiries and applications should be sent by March 1, 1989 to: Dr. Kari O. Raivio, University of Helsinki, Children's Hospital, 00290 Helsinki, Finland. 